\section{Granulozyten, segmentkernige}

H. Baum

Institut für Laboratoriumsmedizin, Mikrobiologie und Blutdepot, Regionale Kliniken Holding RKH GmbH, Ludwigsburg, Deutschland

Synonym(e) Granulozyt, neutrophiler polymorphkerniger

Englischer Begriff polymorphonuclear granulocyte

Definition Sich oxyphil anfärbende, reifste Zelle der Myelopoese mit segmentiertem Kern.

Beschreibung Der segmentkernige Granulozyt ist die reifste Zellform der Granulozytopoese. Die Abbildung zeigt einen neutrophilen segmentkernigen Granulozyten $(1000 \times$, MayGrünwald-Giemsa-Färbung):

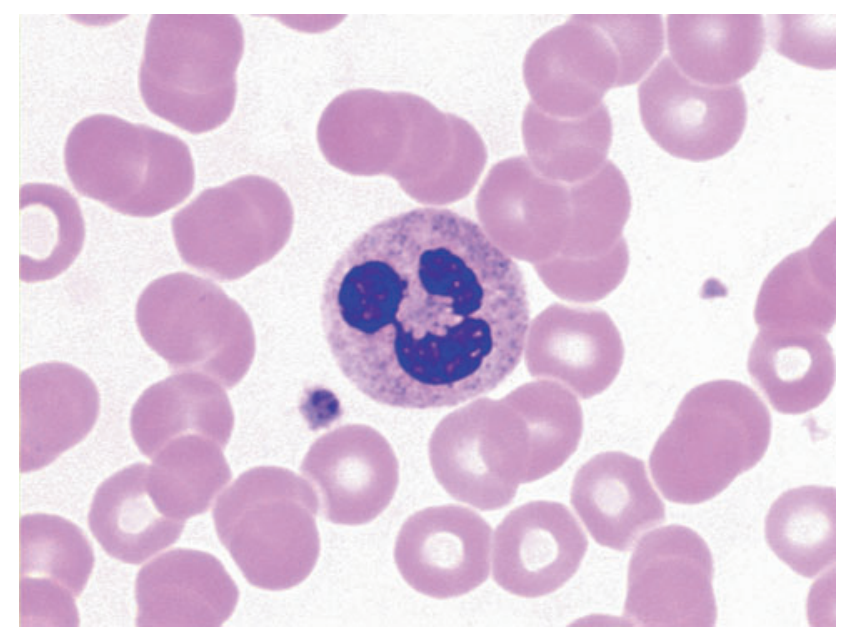

Er ist eine etwa $15 \mu \mathrm{m}$ große Zelle mit einem in $2-4$ Segmente geteilten, rotviolett-gefärbten Kern mit grober Chromatinstruktur, die durch schmale, fadenförmige Chromatinbrücken miteinander verbunden sind. Diese Brücken sollen nicht dicker sein als 1/3 des durchschnittlichen Kerndurchmessers. Die Anzahl der Segmente ist ein Hinweis auf das Alter der Zelle. Jüngere neutrophile Granulozyten haben weniger Kernsegmente, ältere dagegen mehr. Das Zytoplasma ist in der $>$ Pappenheim-Färbung schwach rosa gefärbt (oxyphil) mit feinen, braunvioletten (spezifischen) Granula. Die Granula enthalten in erster Linie D Lysozym, Cobalamin-bindendes Protein und Laktoferrin, Kollagenase und C5-spaltendes Enzym. Neutrophile Granulozyten werden durch chemotaktische Signale angelockt, sie phagozytieren Mikroorganismen und töten diese durch die Kombination von Sauerstoffradikalen und zytotoxischen Proteinen.

\section{Literatur}

Huber H, Nachbaur D, Pastner D (1992) Neutropenien und Funktionsdefekte der Neutrophilen - Physiologie der Granulopoese. In: Huber H, Löffler H, Pastner D (Hrsg) Diagnostische Hämatologie. Springer, Berlin/Heidelberg/New York, S 730-740 